\title{
GENETIC AND ENVIRONMENTAL FACTORS IN HUMAN CARCINOGENESIS
}

\author{
DAVID SCHOTtenFelD \\ Department of Epidemiology, School of Public Health, University of Michigan, \\ Ann Arbor, MI 48109, U.S.A
}

\section{INTRODUCTION}

\begin{abstract}
"Thus the creation of a cancer cell is thought to involve a sequence of events of which perhaps only the early steps bear any direct relation to the interaction between mutagen and DNA. This is borne out by the observation that the later events can be caused by other agents (promoters) that are not themselves mutagenic."
\end{abstract}

John Cairns (1981) [1]

MOST HUMAN cancers are triggered or propagated by exposure to environmental agents. Carcinogenesis is an expression of a complex interplay between exogenous factors that may be inhaled, ingested, or absorbed through the skin, and the evoked responses in the host that are under genetic control. Conversion of a normal cell to neoplastic phenotype involves molecular activation and expression of transforming genes. Transformation of a normal cell to a cancer cell represents a self-perpetuating programming error, a genetic malfunctioning of the integrated control systems for cell proliferation and differentiation.

The "sudden" clinical expression of a malignant neoplasm obscures recognition that symptomatic cancer is the phenotypic endpoint of a sequence of molecular and biochemical events occurring over an induction-latency period measured in years. In experimental systems, the length of the latency period varies with the type and dose of the tumorigenic agent, intrinsic susceptibility of target cells modulated by host immunogenetic characteristics, and tumor growth kinetics. The natural history of neoplastic development evolves through stages of initiation, promotion and autonomous progression. Initiation is a stochastic, multistep process that involves one or more generally irreversible, heritable alterations in the basic structure of cellular DNA that may have been induced by such diverse factors as genotoxic chemicals, ionizing radiation or oncogenic viruses. As defined by Farber [2], promotion is the "process whereby an initiated tissue... develops focal proliferations, one or more of which may act as precursors for subsequent steps in the carcinogenic process." The rate of progression of promotional steps in response to exogenous and endogenous growth promoting factors is dose dependent and may exhibit a measurable threshold as well as a maximal response. The critical molecular events are associated with selective proliferation and altered gene expression. The phenotypic features of autonomous progression are exponential growth, increased invasiveness, and alterations in the biochemical, morphologic, and karyotypic characteristics of the neoplasm [3].

Various multistage and multihit quantitative models for carcinogenesis have been proposed to accommodate a conceptual framework for interpreting experimental and epidemiological data. A highly desirable property of a model would be that it enables testing or validation through experimentation and human observational study. The effective use of mathematical models requires an appreciation of underlying biologic and 
mathematical principles. Multistage models have been proposed to fit or predict agespecific incidence patterns for human cancers, and to provide a mechanistic framework for interpreting the dynamic features of malignant cell transformation in the context of the inherent growth kinetics of normal target tissue.

\section{UNIFYING CONCEPT OF CARCINOGENESIS}

"... diversity of input and commonality of output."

$$
\text { Emmanual Farber (1982) [2] }
$$

A multistage model of carcinogenesis implies that more than one rate determining step is necessary to transform a normal cell into a cancer cell. In most such models, age-specific incidence is proportional to the product of the rate constants for each transformational and evolutionary stage. In the two-stage (mutation) model of carcinogenesis advanced by Moolgavkar and Knudson [4], the clonal origin and stem cell evolution of cancer, and the nature and number of mutations are basic concepts concerning genetic events critical to human tumor development. A clonogenic stem cell model system of carcinogenesis postulates that damage to DNA results in the loss of normal control and regulation of stem cell proliferation and differentiation which disturbs the dynamic balance of transitional cell production, stem cell self-renewal, terminal differentiation and cell loss in target tissue.

Boveri [5] deduced from his studies of sea urchin development in the early 1900's that a malignant tumor originated from a single cell. He concluded that this aberrant somatic cell, as a result of mitotic error, acquired an abnormal chromosome constitution as an intervening primary event in tumor development. In a contemporary context, one or more of the stages in carcinogenesis may be viewed as involving heritable alterations in gene structure and function. The multifactorial causes of human cancers appear to impact upon a genetically responsive substrate within the cell.

\section{Proto-oncogene activation}

A series of discoveries within the past 10 years have begun to illuminate the molecular basis of human neoplasia. Oncogenes, previously thought to exist exclusively in animal tumor viruses such as the RNA retroviruses and DNA papovaviruses, have apparently been carefully preserved throughout vertebrate evolution. DNA sequences that have been identified in retroviral onc genes are homologous to segments present in normal human cellular DNA and in tumor cell DNA. The presence of homologous DNA sequences in both human tumors and viral transforming genes is of considerable interest, since information about the biochemistry and mechanisms of action of oncogenic retroviruses may shed light on the molecular evolution of human tumors. The human genome contains a relatively limited number of structurally and functionally distinctive genes designated as proto-oncogenes that presumably function in normal cell division and growth. The proto-oncogenes are widely distributed throughout the human genome and appear to be strategic targets for perturbation by carcinogens [6].

Dissection of the human genome has revealed at least 20 cellular proto-oncogenes. Different subgroups or families of cellular proto-oncogenes and oncogenes appear to exert different or distinctive effects through their encoded proteins. The experimental approaches employed to identify the structure and function of human and animal cellular oncogenes include exploiting mechanisms by which retroviruses acquire sequences of host DNA, and performing transfection assays of cellular DNA in NIH/3T3 mouse fibroblast cells. Using restriction enzyme techniques, DNA may be progressively broken down into fragments that are analyzed for in vitro transformation capabilities. The structure of the transforming oncogene may then be identified by means of nucleic acid hybridization to radioactive probes and cloned by means of recombinant-DNA technology [7].

Enhancement of human proto-oncogene activity may occur through the inscrtion of retroviral DNA, or, more commonly, somatic mutational events that do not involve 
Table 1. Mechanisms of proto-oncogene activation

\begin{tabular}{|c|c|c|}
\hline Mechanism & Process & Consequence \\
\hline Amplification & $\begin{array}{l}\text { Increase in number of } \\
\text { copies of oncogene }\end{array}$ & $\begin{array}{l}\text { Chromosomal markers of homogeneously staining regions and double } \\
\text { minute chromosomes; } \\
\text { Increased level of messenger RNA; } \\
\text { Enhanced malignant growth potential; } \\
\text { Examples of proto-oncogene amplification in human cancer cell lines: } \\
\quad c-m y c \text { in small cell lung cancer; } \\
N \text {-myc in neuroblastoma, and } c-e r b \text { B-l in glioblastoma multiforme } \\
\text { and squamous cell carcinomas } \\
\text { Mechanism for chemotherapy resistance of cancer cells }\end{array}$ \\
\hline $\begin{array}{l}\text { Chromosomal } \\
\text { rearrangement }\end{array}$ & $\begin{array}{l}\text { Translocation } \\
\text { Deletion }\end{array}$ & $\begin{array}{l}\text { Deregulation of translocated } c-m y c \text { from chromosome } 8 \text {, Burkitt's } \\
\text { lymphoma, and of translocated } c \text {-abl from chromosome } 9 \text {, chronic } \\
\text { myelogenous leukemia; } \\
\text { Deletion of repressive genes, as on chromosome } 3 \text {, small cell carcinoma } \\
\text { lung; chromosome } 13 \text {, retinoblastoma; chromosome } 11 \text {, Wilms tumor }\end{array}$ \\
\hline DNA insertion & $\begin{array}{l}\text { Transposition of } \\
\text { endogenous cellular } \\
\text { DNA sequences } \\
\text { containing regulatory } \\
\text { signals }\end{array}$ & $\begin{array}{l}\text { Increased messenger RNA as in } c-m o s \text { proto-oncogene-murine plasma- } \\
\text { cytoma, Burkitt's lymphoma }\end{array}$ \\
\hline $\begin{array}{l}\text { Acquisition of } \\
\text { transcriptional } \\
\text { promoter }\end{array}$ & $\begin{array}{l}\text { Integration of proviral } \\
\text { DNA segment, as in } \\
\text { retroviral activation }\end{array}$ & $\begin{array}{l}\text { Enhanced transcriptional activity: I Ia-ras (rat); myc and erb B, avian } \\
\text { hempatopoietic neoplasias }\end{array}$ \\
\hline $\begin{array}{l}\text { Base mutation in } \\
\text { coding sequences }\end{array}$ & $\begin{array}{l}\text { Alteration in DNA } \\
\text { codon }\end{array}$ & $\begin{array}{l}\text { New gene product with altered activity, as in } c \text {-ras, the homologue of } \\
\text { Harvey murine sarcoma virus, associated with human carcinomas }\end{array}$ \\
\hline
\end{tabular}

the integration of viral DNA. The various molecular mechanisms of proto-oncogene activation may serve to initiate and promote somatic events that evolve sequentially along a common pathway of tumorigenesis (Table 1). Activated oncogenes have been detected by transfection focal assays in DNA preparations from human carcinomas of the bladder, lung, breast, pancreas, colon and prostate, and neuroblastomas, leukemias, lymphomas and sarcomas. Other transforming genes will undoubtedly be isolated in tumor-DNA preparations from human solid tumors, leukemias and lymphomas, although such discoveries may require transfection to recipient cells other than mouse fibroblasts. The abnormal transforming activity within a DNA sequence, as shown by recombinant-DNA technology, may result in part from a single base change or point mutation in a codon that corresponds to an alteration in one amino acid, or from heightened transcription or overproduction of messenger RNA as a result of insertional gene rearrangement [8].

Tumorigenesis is a multistep process, which may involve cooperative interaction between different proto-oncogenes and the elaboration of transforming growth factors. The protein products of some of the cellular oncogenes appear to be linked with growth regulation, as suggested by the analysis of nucleotide sequences that are homologous to the normally present platelet-derived growth factor or epidermal growth factor [9]. Indeed, it is the concept of unregulated autocrine secretion of growth factors that may provide an explanation for the autonomous proliferation of cancer cells [10]. In addition to protooncogenes, there are likely to be other classes of gene alterations, such as anti-oncogenes and modulating genes, as well as epigenetic events, which affect the origin, expansion and progression of human cancers.

Knudson [11] proposed that cancer may arise when two genes at a critical locus are inactivated. His two-mutation model for the origin of cancer was developed initially to explain familial and non-familial retinoblastoma. In hereditary retinoblastoma, the mutant or deleted locus, $13 \mathrm{q} 14$, with linkage to the locus for esterase D activity, is inherited in an autosomal dominant pattern. The somatic retinal cells of the person inheriting the mutation are heterozygous, but phenotypically appear normal. The second step would be somatic inactivation by various mechanisms of the remaining normal allele. In sporadic, non-familial retinoblastoma, both loci are affected by somatic mutational events. A similar phenomenon has been interpreted for Wilms' tumor, with deletion of the $11 \mathrm{p} 13$ locus. The familial form of retinoblastoma, in contrast to the non-familial, is manifested by earlier 
age at onset, and greater tendency for bilaterality, multicentricity, and associated radiation-induced bone sarcomas [12].

It is the absence of normal gene function in the $13 \mathrm{q} 14$ region that predisposes to retinoblastoma. Comings [13] suggested that expression of a proto-oncogene, particularly in the hereditary cancers, might involve an inherited mutation of a regulatory gene, or anti-oncogene. Subsequent somatic mutation for the homologous regulatory gene might lead to loss of suppression of the transforming gene and, hence, tumor development. The natural history of retinoblastoma has served as the prototypic model for implication of the presence of anti-oncogenes or "suppressor" genes. The anti-oncogene operates in a recessive mode, because one normal allele is sufficient to protect against the expression of risk for a particular cancer. This is in contrast to the mechanism of action of an oncogene, in which a normal or slightly altered gene functions inappropriately or in an augmented fashion, unresponsive to normal regulatory signals [14].

\section{CHROMOSOMAL FRAGILE SITES AND GENE REARRANGEMENTS}

"There is little doubt that genomes of some if not all organisms are fragile and that drastic changes may occur at rapid rates. These can lead to new genomic organizations and modified controls of type and time of gene expression."

Barbara McClintock (1978) [15]

Genomic changes of various kinds, such as base substitutions, deletions and duplications, amplifications and rearrangements through reciprocal translocations or inversions are characteristic of malignant neoplastic cells. With the methotrexate cell synchronization high-resolution banding technique, chromosomal defects have been identified in most patients with leukemia or lymphoma, and with increasing frequency in various solid tumors in children and adults $[16,17]$.

Chromosomal instability and fragility may be viewed as an intrinsic expression of the neoplastic process. Such rearrangements occur at sites that regulate transcription of oncogenes, or within segments of DNA that, as a consequence, encode altered proteins with abnormal mitogenic activity [18].

\section{Chronic myelogenous leukemia}

Nowell and Hungerford [19] reported in 1960 that a specific chromosome abnormality, later designated as the Philadelphia or $\mathrm{Ph}^{1}$ chromosome was consistently associated with chronic myelogenous leukemia. This discovery was made possible by a technical innovation in cytogenetics, even before banding, whereby hyposmotic treatment of cells enabled better spreading of metaphase chromosomes. Chronic myelogenous leukemia is a myeloproliferative disorder characterized by abnormal proliferation of hematopoietic precursor cells, the clonal progeny of a single neoplastic stem cell. The stem cell is affected by reciprocal translocation involving chromosomes 9 and 22. The Philadelphia chromosome, which is demonstrable in $90-95 \%$ of patients with chronic myelogeneous leukemia, results from the exchange of distal segments of each chromosome. In situ chromosomal hybridization has revealed that the breakpoint on chromosome 9 is close to band q34 where the $a b l$ oncogene is located. The $a b l$ oncogene rearranges with gene $b c r$ from chromosome 22, producing an abnormal transcript, an $a b l-h c r$ hybrid RNA, which is translated into an abnormal protein with tyrosine kinase activity. The activation of the oncogene in its translocated setting contributes to a selective growth advantage of the affected cell [20].

\section{Burkitt's lymphoma}

The first clinical and pathological description of Burkitt's lymphoma was published more than 25 years ago [21]. This B-cell lymphoma is the most common cancer of children in areas of both East and West Africa, although it has a low incidence world-wide. Burkitt lymphoid tumor cell lines consistently exhibit a reciprocal translocation of chromosome 
8 with either chromosome $14(75 \%), 22(16 \%)$ or $2(9 \%)$. Chromosomes 14,22 and 2 contain coding sequences that are involved in immunoglobulin production. With the use of a radioactively labeled probe containing genetic sequences almost identical with the $v-m y c$ oncogene of the avian myelocytomatosis virus, which is causally linked with a B-cell lymphoma in chickens, it was determined that a homologous human $c-m y c$ oncogene was located within the breakpoint band of chromosome 8q24.1. Thus, the juxtaposition in B-lymphocytes of an oncogene $(c-m y c)$ to the encoding sequences for heavy chains (chromosome 14) or light chains (chromosomes 2 or 22) of antibody molecules reflects a cytogenetic aberration with pathogenic implications. Translocation of the oncogene alters its normal regulatory control, enhances functional transcription, and ultimately facilitates B-cell malignant transformation [22].

The epidemiologic features of Burkitt's lymphoma have suggested a multi-stage model of pathogenesis. The Epstein-Barr viral genome has been identified in cultured tumor cells in more than $90 \%$ of the cases in Africa where the disease is endemic. In contrast, where the disease occurs sporadically, the Epstein-Barr virus has been identified in $15-20 \%$ of cases. Primary infection of B lymphocytes with the Epstein-Barr virus may serve in most, but not all instances, to stimulate a polyclonal B-cell proliferation, a necessary precursor event in B-cell neoplastic conditions. Other chronic infections, such as falciparum malaria and/or associated immune deficiency disorders, sustain a high turnover of the lymphocyte population. The ultimate monoclonal neoplastic conversion is signaled by cytogenetic and molecular events that have been described previously [23, 24].

\section{TUMOR PROMOTERS IN HUMAN CARCINOGENESIS}

"The natural history of the development of human neoplasia is not distinguishably different from that in animal models."

Roswell K. Boutwell (1985) [25]

We have previously considered how loss or alteration of regulatory genes may be accompanied by augmented expression of cellular oncogenes, and that these molecular events comprise steps in a common pathway leading to malignant transformation. All too often the initiating trigger for such a cascade of events is unknown, although epidemiologic research has identified a varied spectrum of lifestyle and environmental causative factors (Tables 2 and 3).

As emphasized by Boutwell [25], although humans are exposed inevitably to carcinogenic agents, both the dose level of a putative initiator in combination with the dose level of exposure to one or more promoting agents determine the rate of development and clinical presentation of malignant tumors. At least three different stages have been defined in the development of neoplasia in experimental systems: initiation, promotion, and progression.

The classical two-stage mouse skin model has shown that epidermal tumors can be induced by the sequential application of a single subcarcinogenic dose of a polycyclic aromatic hydrocarbon (initiation stage), followed by repetitive applications with another class of agent, such as croton oil or a phorbol ester (promotion stage). A single large dose of the initiator, such as 7, 12-dimethylbenz(a)anthracene (DMBA), without the application of any other agent, is capable of inducing skin tumors in mice. Papillomas appear initially within 10-20 weeks, and carcinomas subsequently within 20-60 weeks. Thus, the application of a very high dose of a carcinogen may lead both to initiation and promotion of tumorigenesis. A single reduced subcarcinogenic dose of DMBA will not give rise to tumors over the lifespan of the mouse, unless it is followed by repeated applications of a promoting agent. Multiple sequential applications of the promoter without, or prior to, initiation by DMBA does not give rise to epidermal tumors. After the initiation phase, the tumor response is ultimately the same, whether the promotional stage is initiated one week or one year later [26]. 


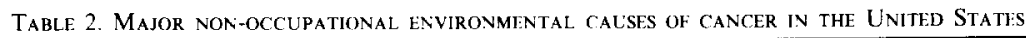

\begin{tabular}{ll}
\hline Agent & \multicolumn{1}{c}{ Organ site(s) } \\
\hline Tobacco & $\begin{array}{l}\text { Larynx. lung, oral cavity, } \\
\text { pharynx, esophagus, } \\
\text { pancreas, kidney, urinary } \\
\text { bladder }\end{array}$
\end{tabular}

Alcohol

Oral cavity, pharynx larynx, esophagus, liver

Ionizing radiation

Hematopoietic, breast bone, thyroid, lung. esophagus, stomach, colon, urinary bladder, connective tissue

Solar radiation

Skin
Medications

Alkylating agents

Androgen-anabolic steroids

Estrogens

Synthetic

non-steroidal

(DES)

Conjugated

(Premarin)

Steroid

contraceptives
Hematopoietic, urinary bladder

Liver (hepatocellular carcinoma)

Vagina (adenocarcinoma)

Endometrium (adenocarcinoma)

Liver, uterine cervix(?)
Contributes to $25-35 \%$ of all cancer deaths in men, $5-10 \%$ in women: $80-85 \%$ of lung cancer deaths. Within the oral cavity, all forms of tobacco smoke and smokeless tobacco are of etiologio significance; to the extent that tobacco juice is swallowed the extrinsic larynx and esophagus are affected. Combination exposures of tobacco with alcohol, asbestos, and ionizing radiation (radon alpha particles) in uranium miners lead to multiplicative effects. For example, miners who have smoked a pack of cigarettes a day for 20 years have radiation-induced lung cancer rates per unit of exposure that are about five times those in miners who do not smoke.

Tobacco smoke consists of more than 3,600 individual compounds. with the major tumorigenic activity contained in the particulate matter of "tar" fraction. Examples of carcinogenic agents include the polynuclear aromatic hydrocarbons and nitrosamines.

Contributes to $3 \%$ of all cancer deaths. Tobacco and alcohol combined account for about $75-85 \%$ of upper digestive tract cancer mortality. Possible mechanisms of co-carcinogenic action include the following:

Local cytotoxicity affecting mucosal permeability;

Presence of low levels of carcinogens in alcoholic beverages (e.g.

fusel, oils, polycyclic aromatic hydrocarbons, nitrosamines);

Induction of microsomal enzymes that activate procarcinogens in remote and target tissues:

Alcoholic liver injury may affect important mechanisms.of chemical detoxification;

Nutritional deficiencies (e $g$, vitamins A, C, riboflavin, and iron) give rise to altered mucosal integrity, enzyme and metabolic dysfunction. and morphologic abnormalities; and

Decreased immune responsiveness.

Natural background radiation may account for $1.5 \%$ of all cancer deaths; occupational exposures and medical uses of ionizing radiation (gamma, beta, and $\mathrm{X}$-rays) account for about $1 \%$. The most radiosensitive tissues are the female breast, thyroid, and hematopoietic tissues. The minimal latency period for solid cancers is about $10 \mathrm{yr}$; and for leukemia, about $2 \mathrm{yr}$

Of major concern are the u.v.-B radiations $(290-320 \mathrm{~nm})$. Skin cancer is predominantly a disease of the white race and is rare in deeply pigmented ethnic and racial groups. In nonmelanoma skin cancer, lesions occur primarily on parts of the body with direct chronic exposure; outdoor workers are at greater risk than indoor workers; incidence is greatest in areas of high insolation and is inversely correlated with latitude. The solar etiology of malignant melanoma is more consistent with intermittent intense exposures, rather than correlated with chronic cumulative exposure. Melanoma incidence is not correlated with outdoor work, is particularly high in upper managerial and professional employment categories, and, in contrast with squamous carcinoma of the skin, is not significantly agedependent. Host factors, such as the familial dysplastic nevus syndrome and acquired immune dysfunction, may serve as predisposing or enhancing characteristics.

Various medications account for about $1 \%$ of all cancer deaths. The alkylating agents are cytotoxic, mutagenic, electrophilic, and clastogenic.

DES acts as a transplacental carcinogen. When administered over a period of years to patients with gonadal dysgenesis, DES has been associated with adenosquamous carcinoma of the endometrium.

The synthetic estrogens and progestins used in many oral contraceptives are 17 alpha alkyl substituted steroids similar in structure to the androgenic anabolic steroids. The combination oral contraceptives are significantly protective with respect to carcinomas of the endometrium and ovary, but do not alter the risk of breast cancer, even among high-risk subgroups. In contrast, studies have suggested that the risk of uterine cervical dysplasia and carcinoma may be increased by longterm use of oral contraceptives.
Immunosuppressants

Phenacetincontaining analgesics
Lymphoreticular, skin. soft tissue

Kidney pelvis 
TABLE 2-continued

\begin{tabular}{|c|c|c|}
\hline Agent & Organ site(s) & Comments \\
\hline $\begin{array}{l}\text { Viruses and } \\
\text { parasites }\end{array}$ & $\begin{array}{l}\text { Burkitt's lymphoma: } \\
\text { Epstein-Barr virus and } \\
\text { malaria are co-factors } \\
\text { Nasopharynx: Epstein- } \\
\text { Barr virus } \\
\text { Liver: Hepatitis B, } \\
\text { liver flukes } \\
\text { Urinary bladder: } \\
\text { Schistosoma (Bilharzia) } \\
\text { hematobium (blood } \\
\text { fluke) } \\
\text { Hematopoietic: Human } \\
\text { T-Cell leukemia } \\
\text { retrovirus--Types I, II } \\
\text { Uterine cervix:? } \\
\text { Herpes simplex } \\
\text { Type II, ? Papilloma } \\
\text { viruses } \\
\text { Kaposi’s sarcoma: } \\
\text { Acquired Immuno- } \\
\text { deficiency Syndrome } \\
\text { (AIDS) }\end{array}$ & $\begin{array}{l}\text { Viral oncogenic agents probably account for } 510 \% \text { of cancer deaths. } \\
\text { The relative importance of each biologic agent varies throughout the } \\
\text { world. } \\
\text { The human T-cell lymphotropic retrovirus Type III is transmitted } \\
\text { by sexual contact or by contaminated blood products or needles. } \\
\text { Increased risk of malignant lymphoma. with origin in central nervous } \\
\text { system or Burkitt-type lymphoma. }\end{array}$ \\
\hline $\begin{array}{l}\text { Dietary deficiencies } \\
\text { and excesses }\end{array}$ & $\begin{array}{l}\text { Oral cavity, esophagus, } \\
\text { stomach, colon, pancreas } \\
\text { and biliary, lung, prostate, } \\
\text { breast, endometrium }\end{array}$ & $\begin{array}{l}\text { International comparisons of site-specific cancer mortality, the } \\
\text { "experiments of nature" provided by migrant studies and case- } \\
\text { control studies have suggested that a substantial etiologic fraction } \\
\text { of some of the major cancer sites in the United States may be } \\
\text { attributable to dietary factors. Thus, it has been estimated that } \\
\text { through dietary modifications we might ultimately achieve a } 35 \% \\
\text { reduction in cancer mortality. Various nutrition hypotheses have } \\
\text { been concerned with excess in dietary fat consumption and the role } \\
\text { of obesity with respect to the incidence of cancers in the colon, } \\
\text { endometrium, breast, and gallbladder, or with deficiencies in fresh } \\
\text { fruits and vegetables with respect to the risk of various gastroint- } \\
\text { estinal tract cancers. }\end{array}$ \\
\hline Pollution & $\begin{array}{l}\text { Respiratory } \\
\text { Large intestine } \\
\text { Urinary bladder }\end{array}$ & $\begin{array}{l}\text { Pollutants in urban air have long been suspected in the etiology of } \\
\text { lung cancer, with fossil fuel combustion products, especially poly- } \\
\text { cyclic hydrocarbons, being of special concern. Some studies have } \\
\text { suggested that tobacco smoke may interact with carcinogens in the } \\
\text { ambicnt atmosphere, or that neighborhood communities may be } \\
\text { affected by airborne pollutants (e.g. asbestos, arsenic, radon) from } \\
\text { industrial sources. Interest has also centered on contaminants in } \\
\text { drinking water, since several halogenated organic compounds (tri- } \\
\text { halomethanes) produced during chlorination are carcinogenic or } \\
\text { mutagenic on laboratory tests. Levels of these compounds in surface } \\
\text { drinking water have been positively correlated with mortality rates } \\
\text { for cancers of the bladder and large bowel. The attributable risk has } \\
\text { been difficult to estimate with any precision, but probably does not } \\
\text { exceed } 1-2 \% \text {. }\end{array}$ \\
\hline
\end{tabular}

Modified after Schottenfeld D: Arch Environ Health 39: 150-157, 1984.

The two-stage model system in mouse skin has been generalized to other mouse organ systems, such as the liver, lung, colon, urinary bladder, mammary gland, stomach, esophagus, pancreas, mouse cell culture systems, and the rat tracheal organ culture system. The critical molecular events in tumor promotion are associated with a mitogenic effect and altered gene expression in initiated stem cells [27].

Various biochemical mechanisms have been explored to clarify the action of different classes of tumor promoters. Promoting agents differ in their effects on different target tissues, and in different animal species. The phorbol esters, for example, induce multiple biochemical effects such as: (a) alteration of cell membrane glycoprotein structure and enzyme activity; (b) stimulation of growth-promoting substances such as proteases, polyamines and prostaglandins; (c) formation of free radicals and activated oxygen; (d) increased turnover of phospholipids; and (e) induction of the enzyme ornithine decarboxylase, which is the rate-limiting enzyme for synthesis of the polyamines putrescine, spermidine and spermine. While it has been recognized that oxygen radicals and peroxides participate in radiation carcinogenesis, it has also been demonstrated that reactive oxygen species are important mediators of chemical toxicity in tumor promotion. Other examples of tumor promoters are contained within the diet, bile acids, food additives, steroid hormones, phenobarbital, cigarette smoke and asbestos [28]. 
TABLE 3. ChEMICAL SUBSTANCES LINKFD WITH THE WORK PLACE WITH SUFFICIENT EVIDENCE OF HUMAN CARCINOGENICITY

\begin{tabular}{|c|c|c|c|}
\hline Agent & Target Organs & $\begin{array}{l}\text { Animal and } \\
\text { Epidemiologic } \\
\text { Studies }\end{array}$ & Comments \\
\hline 4-Aminobiphenyl & Urinary bladder: & $\begin{array}{l}\text { mouse, ral. } \\
\text { rabbit; } \\
\text { human }\end{array}$ & $\begin{array}{l}\text { Formerly used as a rubber antioxidant and as a dye } \\
\text { intermediate. }\end{array}$ \\
\hline $\begin{array}{l}\text { Arsenic and } \\
\text { arsenic } \\
\text { trioxide } \\
\text { compounds }\end{array}$ & Skin, lung: & $\begin{array}{l}\text { liuman: animal } \\
\text { data incon- } \\
\text { clusive }\end{array}$ & $\begin{array}{l}\text { Over } 95 \% \text { of arsenic produced in the Unisted States is } \\
\text { a by-product of copper and lead ore smelting. Excess } \\
\text { lung cancer has been reported in association with } \\
\text { use and production of inorganic trivalent arsenic- } \\
\text { containing pesticides as well as metal smelting oper- } \\
\text { ations. An estimated } 545,000 \text { workers are potentially } \\
\text { exposed. Occupation Safety and Health Administration } \\
\text { (OSHA) standard for limiting occupational exposure is } \\
10 \mu \mathrm{g} / \mathrm{m}^{3} \text {. }\end{array}$ \\
\hline Asbestos fibers & $\begin{array}{l}\text { Lung, pleura and } \\
\text { peritoneum: }\end{array}$ & $\begin{array}{l}\text { mouse, rat, } \\
\text { hamster. } \\
\text { rabbit; } \\
\text { human } \\
\text { human } \\
\text { human }\end{array}$ & $\begin{array}{l}\text { The four commercially important forms are chrysotile, } \\
\text { amosite, anthophyllite, and crocidolite. Chrysotile repre- } \\
\text { sented } 94 \% \text { of United States production and consumption } \\
\text { in the } 1970 \mathrm{~s} \text {. About } 2.5 \text { million workers are estimated to } \\
\text { have some exposure. Combined cigarette smoking and } \\
\text { ashestos exposure increase lung cancer risk multiplicat- } \\
\text { ively. Asbestos exposure in the United States accounts for } \\
\text { approximately } 5 \% \text { of lung cancer deaths and } 1-2 \% \text { of all } \\
\text { cancer deaths in men. OSHA standard is } 2 \text { fibers } / \mathrm{cm}^{3} \text { of } \\
\text { air for fibers longer than } 5 \mu \mathrm{m} \text {. }\end{array}$ \\
\hline
\end{tabular}

\begin{tabular}{|c|c|c|}
\hline $\begin{array}{l}\text { Auramine (Basic } \\
\text { Yellow 2) }\end{array}$ & $\begin{array}{l}\text { Liver: } \\
\text { Bladder: }\end{array}$ & $\begin{array}{l}\text { mouse, rat } \\
\text { human }\end{array}$ \\
\hline Benzene & $\begin{array}{l}\text { Zymbal gland: } \\
\text { Lymphoid: } \\
\text { Bone marrow: }\end{array}$ & $\begin{array}{l}\text { rat } \\
\text { mice(?) } \\
\text { human } \\
\text { (primarily, } \\
\text { acute non- } \\
\text { lymphocytic } \\
\text { leukemia) }\end{array}$ \\
\hline Benzidine & $\begin{array}{l}\text { Liver: } \\
\text { Bladder: }\end{array}$ & $\begin{array}{l}\text { mouse, rat, } \\
\text { hamster } \\
\text { dog; human }\end{array}$ \\
\hline $\begin{array}{l}\text { Bis (chloro- } \\
\text { methyl) ether } \\
\text { and chloro- } \\
\text { methyl methyl } \\
\text { ether }\end{array}$ & $\begin{array}{l}\text { Lung: } \\
\text { Connective tissue: }\end{array}$ & $\begin{array}{l}\text { mouse; human } \\
\text { (oat cell) } \\
\text { rat, mouse } \\
\text { (sarcoma } \\
\text { at site of } \\
\text { injection) } \\
\text { mouse }\end{array}$ \\
\hline $\begin{array}{l}\text { Chromium and } \\
\text { compounds }\end{array}$ & $\begin{array}{l}\text { Lung: } \\
\text { Nasal sinuses: } \\
\text { Kidney: } \\
\text { Connective tissue: }\end{array}$ & $\begin{array}{l}\text { rat; human } \\
\text { human } \\
\text { rat } \\
\text { rat (sarcoma } \\
\text { at site of } \\
\text { injection) }\end{array}$ \\
\hline $\begin{array}{l}\text { Coke oven } \\
\text { emissions }\end{array}$ & $\begin{array}{l}\text { Lung: } \\
\text { Urinary tract: } \\
\text { Connective tissue: }\end{array}$ & $\begin{array}{l}\text { mouse, rat: } \\
\text { human } \\
\text { human } \\
\text { mouse, rat } \\
\text { (sarcoma } \\
\text { at site of } \\
\text { injection) } \\
\text { mouse, rat }\end{array}$ \\
\hline $\begin{array}{l}\text { Hematite } \\
\text { underground } \\
\text { mining (iron } \\
\text { ore, iron oxides) }\end{array}$ & Lung: & $\begin{array}{l}\text { human; no car- } \\
\text { cinogenic } \\
\text { effects were } \\
\text { observed in } \\
\text { the mouse, } \\
\text { hamster, or } \\
\text { guinea pig } \\
\text { given ferric } \\
\text { oxide intra- } \\
\text { tracheally }\end{array}$ \\
\hline
\end{tabular}

Used industrially as a dye or dye intermediate for coloring textiles, leather, and paper. Approximately 3000 workers are potentially exposed.

Used extensively in industry as a solvent and a starting material or intermediate in production of cyclic hydrocarbons. An estimated 3 million workers are potentially exposed. OSHA regulation for a permissible exposure limit is $10 \mathrm{ppm}$ in air for an 8-hour time-weighted average. Chromosomal aberrations and aplastic anemia may follow toxic exposures.

Aromatic amine used as an intermediate in the production of dyes. An estimated 2200 workers are potcntially exposed. Annual production has decreased significantly in the United States.

Used in the manufacture of plastics and ion exchange resins. No estimates are available for number of workers exposed

Used in metal alloys, electroplating, magnetic tapes, pigment for paints, cement, rubber, composition floor covering, and as oxidant in synthesis of organic chemicals. An estimated 2.5 million workers are exposed to chromium and its compounds. OSHA regulation has adopted 8 -hour time-weighted average exposure limits of $0.5 \mathrm{mg} / \mathrm{m}^{3}$ for soluble chromium compounds, $1 \mathrm{mg} / \mathrm{m}^{3}$ for chromium metal and insoluble compounds and exposure level of $0.1 \mathrm{mg} / \mathrm{m}^{3}$ for chromic acid and hexavalent chromates.

Complex mixture of products of coal combustion and distillation comprised of polycyclic aromatic hydrocarbons OSHA has estimated that 10,000 workers are exposed to these emissions. OSHA standard of exposure is $150 \mu \mathrm{g} / \mathrm{m}^{3}$ averaged over any 8-hour period.

Ingestion and inhalation of dusts which contain iron oxides, silica, and even radon. The contribution of factors other than ferric oxide to increased lung cancer mortality in the underground hematite miners is unknown. 
TABLE 3 - continued

\begin{tabular}{|c|c|c|c|}
\hline Agent & Target Organs & $\begin{array}{l}\text { Animal and } \\
\text { Epidemiologic } \\
\text { Studies }\end{array}$ & Comments \\
\hline $\begin{array}{l}\text { Isopropyl alcohol } \\
\text { manufacture } \\
\text { (strong-acid } \\
\text { process) }\end{array}$ & $\begin{array}{l}\text { Paranasal sinuses: } \\
\text { Larynx: } \\
\text { Lung: }\end{array}$ & $\begin{array}{l}\text { human } \\
\text { human } \\
\text { mouse; human }\end{array}$ & $\begin{array}{l}\text { The strong suifuric acid process in the manutacture of } \\
\text { isopropyl alcohol leaves a residue of isopropyl oils and } \\
\text { diisopropyl sufate and diethyl sulfate. It is not clear } \\
\text { whether one or more of these substances is a respiratory } \\
\text { tract carcinogen. The primary commercial uses of iso- } \\
\text { propyl alcohol are in acetone production and as a solvent } \\
\text { or chemical intermediate. About } 141,000 \text { workers are } \\
\text { potentially exposed to the isopropyl manufacturing pro- } \\
\text { cess in the United States. }\end{array}$ \\
\hline Mustard gas & $\begin{array}{l}\text { Lung: } \\
\text { Connective tissue: }\end{array}$ & $\begin{array}{l}\text { mouse; human } \\
\text { mouse } \\
\quad \text { (sarcoma } \\
\text { at site of } \\
\text { injection) }\end{array}$ & $\begin{array}{l}\text { Mustard gas was used in chemical warfare during World } \\
\text { War I, and production and stockpiling of this chemical } \\
\text { was maintained during World War II. It has been tested } \\
\text { as a prototype compound for antineoplastic alkylating } \\
\text { agents. Lung cancer mortality increased among workers } \\
\text { with chronic exposures. }\end{array}$ \\
\hline$\beta$-naphthylamine & Bladder: & $\begin{array}{l}\text { hamster, dog, } \\
\text { monkey; } \\
\text { human } \\
\text { mouse }\end{array}$ & $\begin{array}{l}\text { Used principally as an intermediate in the manufacture of } \\
\text { dyes and as an antioxidant in the rubber industry. Little } \\
\text { commercial production in the United States during the } \\
\text { past } 10 \mathrm{yr}\end{array}$ \\
\hline $\begin{array}{l}\text { Nickel refining } \\
\text { and nickel } \\
\text { compounds }\end{array}$ & $\begin{array}{l}\text { Lung: } \\
\text { Nasal passages: } \\
\text { Larynx: } \\
\text { Connective tissue: }\end{array}$ & $\begin{array}{l}\text { rat; human } \\
\text { human } \\
\text { human } \\
\text { rat, hamster } \\
\text { (sarcoma } \\
\text { at site of } \\
\text { injection) }\end{array}$ & $\begin{array}{l}\text { Used in electroplating, manufacturing of steel and other } \\
\text { alloys, ceramics, storage batteries, electric circuits, petro- } \\
\text { leum refining, and oil hydrogenation. An estimated } \\
710.000 \text { workers are potentially exposed. OSHA standard } \\
\text { is } 0.007 \mathrm{mg} / \mathrm{m}^{3} \text { for nickel carbonyl and } 1 \mathrm{mg} / \mathrm{m}^{3} \text { for metal } \\
\text { and soluble compounds. }\end{array}$ \\
\hline $\begin{array}{l}\text { Soots, tars, and } \\
\text { mineral oils } \\
\text { (including } \\
\text { creosote, shale, } \\
\text { and cutting oils) }\end{array}$ & $\begin{array}{l}\text { Skin, scrotum: } \\
\text { Lung: } \\
\text { Bladder: } \\
\text { Gastrointestinal: }\end{array}$ & $\begin{array}{l}\text { experimental } \\
\text { human } \\
\text { human } \\
\text { human }\end{array}$ & $\begin{array}{l}\text { These substances result from fossil fuel processing tech- } \\
\text { nology, and represent mixtures of aromatic hydrocarbons. } \\
\text { Precise risk varies with nature of mixture and nature } \\
\text { and route of exposure (i.e. skin absorption, inhalation, } \\
\text { ingestion). }\end{array}$ \\
\hline Vinyl chloride & $\begin{array}{l}\text { Liver (angio- } \\
\text { sarcoma): } \\
\text { Brain: } \\
\text { Lung: } \\
\text { Lymphoreticular (?): }\end{array}$ & $\begin{array}{l}\text { human } \\
\text { rat; human } \\
\text { human } \\
\text { human }\end{array}$ & $\begin{array}{l}\text { Principal use is in production of plastics, packaging } \\
\text { materials, and vinyl asbestos foor tiles. More than } 3.5 \text { mil- } \\
\text { lion workers are potentially exposed. Its use as an aerosol } \\
\text { propellant was banned by the EPA, FDA, and CPSC. } \\
\text { OSHA standard is } 1 \text { ppm as an } 8 \text {-hour time-weighted } \\
\text { average and a } 5 \text { ppm ceiling for any } 15 \text {-minute period. }\end{array}$ \\
\hline
\end{tabular}

Reprinted with permission of the publisher: Arch Environ Health 39: 150-157, 1984

\section{INHERITANCE OF CANCER SUSCEPTIBILITY}

"Cancer is essentially a genetic disease at the cellular level."

$$
\text { W. F. Bodmer (1982) [29] }
$$

A major objective of molecular studies of carcinogenesis would be to determine the location of genes involved in modulating susceptibility, and to establish biochemical and immunologic mechanisms of pathogenesis. The existence of genetically determined pathologic conditions, or even more subtle metabolic processes, that alter our ability to cope with environmental mutagens, should challenge the epidemiologist to view the carcinogenic process as a complex and dynamic interaction of environment and heredity [30]. Indeed, "ecogenetics", or the study of genetic variability in response to specific environmental agents, is analogous to the concern in pharmacogenetics of host variability with respect to therapeutic response, toxicity, metabolism and biotransformation. The ultimate outcome of exposure to potential carcinogens may depend on competitive gene-enzyme interactions that affect activation or detoxification, or on the integrity of endogenous mechanisms for repairing lesions in DNA [31, 32].

\section{REFERENCES}

1. Cairns J: The origin of human cancers. Nature 289: 353-357, 1981

2. Farber E: Sequential events in chemical carcinogenesis. In Cancer: A Comprehensive Treatise 2nd edn. Becker FE (Ed). New York: Plenum. 1982, pp. 485-506

3. Scott RE, Wille JJ Jr, Wier ML: Mechanisms for the initiation and promotion of carcinogenesis: A review and a new concept. Mayo Clin Proc 59: 107-117, 1984 
4. Moolgavkar SH, Knudson AG $\mathbf{J} r$ : Mutation and cancer: A model for human carcinogenesis. $\mathbf{J}$ Natl Cancer Inst 66: 1037-1052, 1981

5. Boveri T: The Origin of Malignant Tumors. Baltimore: Williams \& Wilkins, 1929

6. Bishop JM: Cellular oncogenes and retroviruses. Ann Rev Biochem 52: 301-354, 1983

7. Krontiris TG: The emerging genetics of human cancer. N Engl J Med 309: 404-409, 1983

8. Land H. Parada LF, Weinberg RA: Cellular oncogenes and multistep carcinogenesis. Science 222: $771-778,1983$

9. Stiles $\mathrm{CD}$ : The biological role of oncogenes-Insights from platelet-derived growth factor. Cancer Res 45 : 5215-5218, 1985

10. Sporn MB, Roberts AB: Introduction: Autocrine, paracrine and endocrine mechanisms of growth control. Cancer Surveys 4: $627 \quad 632,1985$

11. Knudson AG Jr: Heredilary cancer, oncogenes, and antioncogenes. Cancer Res 45: 1437--1443, 1985

12. Strong LC: Mutational models for cancer etiology. In Genetics in Clinical Oncology, Chaganti RSK. German JL (Eds). New York: Oxford, 1985 pp. 39-59

13. Comings DE: A general theory of carcinogenesis. Proc Natl Acad Sci 70: 3324-3328, 1973

14. Green AR, Wyke JA: Anti-oncogenes: A subset of regulatory genes involved in carcinogenesis? Lancet 2: 475-477, 1985

15. McClintock B: Mechanisms that rapidly reorganize the genome. In Stadler Symposium, Reden GP (Ed). Columbia, MO: Curator of University of Missouri, 1978. pp. 25-48

16. Yunis JJ: Chromosomal rearrangements, genes, and fragile sites in cancer: Clinical and biologic implications. In Important Advances in Oncology, DeVita VT, Hellman S, Rosenberg SA (Eds). Philadelphia: J. B. Lippincott, 1986. pp. 93-128

17. Rowley JD: Biological implications of consistent chromosome rearrangements in leukemia and lymphoma. Cancer Res 44: 3159-3168, 1984

18. Dewald GW, Noel P, Dahl RJ, Spurbeck JL: Chromosome abnormalities in malignant hematologic disorders. Mayo Clin Proc 60: 675 689, 1985

19. Nowell PC, Hungerford DA: A minute chromosome in human chronic granulocytic leukemia. Science 132: 1497, 1960

20. Sokal JE, Gomez GA: The Philadelphia chromosome and Philadelphia chromosome mosaicism in chronic granulocytic leukemia. J Clin Oncol 4: 104-111, 1986

21. Burkitt DP: A sarcoma involving the jaws in African children. Br J Surg 197: 218-223, 1958

22. Croce CM: Gene regulation in the expression of malignancy. Cancer Surveys 3: 287-298, 1984

23. Purtilo DT, Manolov G, Manolova Y, Harada S, Lipscomb H. Tatsumi E: Role of Epstein-Barr virus in the etiology of Burkitt's lymphoma. In Burkitt's Lymphoma, Lenoir G, O'Conor G, Olweny CLM (Eds). Lyon, France: IARC Publications No. 60, 1985. pp. 231-247

24. Potter M, Mushinski JF: Oncogenes in B-cell neoplasia. Cancer Invest 2: 285-300, 1984

25. Boutwell RK: Tumor promoters in human carcinogenesis. In Important Advances in Oncology, DeVita VT, Hellman S, Rosenberg SA (Eds). Philadelphia: JB Lippincott, 1985. pp. 16-27

26. Montesano R, Slaga TJ: Initiation and promotion in carcinogenesis: An appraisal. Cancer Surveys 2 : 613-621 1983

27. Pitot $\mathrm{HC}$ : Contributions to our understanding of the natural history of neoplastic development in lower animals to the cause and control of human cancer. Cancer Surveys 2: 519-537, 1983

28. Yuspa S, Harris C: Molecular and cellular basis of chemical carcinogenesis. In Cancer Epidemiology and Prevention, Schottenfeld D, Fraumeni JF Jr (Eds). Philadelphia: W. B. Saunders, 1982. pp. 23-43

29. Bodmer WF: Cancer geneties. Cancer Surveys 1: 1 15, 1982

30. Strong LC: Genetic-environmental interactions. In Cancer Epidemiology and Prevention, Schottenfeld D, Fraumeni JF, Jr (Eds). Philadelphia: W. B. Saunders, 1982. pp. 506-516

31. Omenn GS: Risk assessment, pharmacogenetics and ecogenetics. In Genetic Variability in Responses to Chemical Exposure, Omenn GS, Gelboin HV (Eds). Banbury Report 16. New York: Cold Spring Harbor Laboratory, 1984. pp. 3-13

32. Lehmann AR: Xeroderma pigmentosum, Cockayne syndrome and ataxia telangiectasia: Disorders relating DNA repair to carcinogenesis. Cancer Surveys 1: 93-118, 1982 